\title{
PENERAPAN MODEL PEMBELAJARAN PROBLEM BASED LEARNING (PBL) UNTUK PENINGKATAN KEMAMPUAN BERPIKIR KREATIF DAN HASIL BELAJAR SISWA DALAM PEMBELAJARAN TEMATIK
}

\author{
Marda Novellia ${ }^{1}$, Stefanus C. Relmasira ${ }^{2}$, Agustina Tyas Asri Hardini ${ }^{3}$ \\ 1,2,3 Jurusan Pendidikan Guru Sekolah Dasar \\ FKIP Universitas Kristen Satya Wacana \\ email: 292014145@student.uksw.edu', stefanus.relmasira@staff.uksw.edu², \\ tyas.asri@staff.uksw.edu ${ }^{3}$
}

\begin{abstract}
Abstrak
Penelitian ini merupakan Penelitian Tindakan Kelas (PTK) yang bertujuan untuk meningkatkan kemampuan berpikir kreatif dan hasil belajar siswa kelas IV SD Negeri Mangunsari 03 Salatiga. Masalah yang ditemukan dalam proses pembelajaran diantaranya siswa cenderung kurang aktif, pembelajaran monoton, sebagian besar siswa cenderung tidak mengajukan pertanyaan dan sebagian siswa kemampuan berpikir kreatifnya masih belum terlihat. Untuk mengatasi permasalahan tersebut peneliti melakukan penelitian tindakan kelas berkaitan dengan penerapan model pembelajaran Problem Based Learning (PBL) untuk meningkatkan kemampuan berpikit kreatif dan hasil belajar siswa kelas IV SD Negeri Mangunsari 03 Salatiga pada Tema 7 Subtema 2 dan 3 semester II. Penelitian ini terdiri dari dua siklus, setiap siklus terdiri dari tiga pertemuan masing-masing terdiri dari perencanaan tindakan, pelaksanaan tindakan, observasi, dan refleksi serta evaluasi. Data dalam penelitian ini diperoleh dari observasi, studi dokumen, dan tes. Peningkatan kemampuan berpikir kreatif siswa dapat ditunjukkan pra siklus presentase kemampuan berpikir kreatif siswa $71,06 \%$ kemudian meningkat pada siklus I dengan presentase $86,84 \%$ kembali meningkat pada siklus II dengan presentase $89,47 \%$. Sedangkan hasil belajar siswa pada pra siklus dengan presentase $55,26 \%$ meningkat pada siklus I dengan presentase $78,94 \%$ dan pada siklus II kembali meningkat dengan presentase $86,84 \%$. Jadi, dengan penerapan model Problem Based Learning (PBL) terbukti dapat meningkatkan kemampuan berpikir kreatif dan hasil belajar siswa Kelas IV SD Negeri Mangunsari 03 Salatiga pada Tema 7 Subtema 2 dan 3.
\end{abstract}

Kata kunci: PTK, Problem Based Learning, Berpikir Kreatif, Hasil Belajar

\begin{abstract}
This research is a Classroom Action Research (PTK) which aims to improve the ability of creative thinking and student learning outcomes fourth grade SD Negeri Mangunsari 03 Salatiga. Problems encountered in the learning process include students tend to be less active, monotonous learning, most students tend not to ask questions and some students' creative thinking ability is still not seen. To overcome these problems, the researcher conducted a class action research related to the application of Problem Based Learning (PBL) learning model to improve creative creativity and learning result of fourth grade students of SD Negeri Mangunsari 03 Salatiga on Theme 7 Subtema 2 and 3 semesters II. The study consists of two cycles, each cycle consisting of three meetings each consisting of action planning, action execution, observation, and reflection and evaluation. The data in this research is obtained from observation, document study, and test. Improvement of students 'creative thinking ability can be shown pre-cycle percentage of students' creative thinking ability $71,06 \%$ then increase in cycle I with percentage $86,84 \%$ again increase in cycle II with percentage $89,47 \%$. While the result of student learning in pre cycle with percentage $55,26 \%$ increase in cycle I with percentage $78,94 \%$ and in cycle II again increase with percentage $86,84 \%$. Thus, with the application of Problem Based Learning (PBL) model proved able to improve the ability of creative thinking and learning outcomes of fourth grade students of SD Negeri Mangunsari 03 Salatiga in Theme 7 Subtema 2 and 3.
\end{abstract}

Keywords: PTK, Problem Based Learning, Berpikir Kreatif, Hasil Belaja 1. Pendahuluan 
Menurut Undang-Undang Nomor 20 tahun 2003 tentang fungsi dan tujuan Sistem Pendidikan Nasional Pasal 3 menyatakan bahwa, pendidikan nasional berfungsi mengembangkan kemampuan dan membentuk watak serta peradaban bangsa yang bermartabat dalam rangka mencerdaskan kehidupan bangsa. Pendidikan memegang peranan penting dalam kehidupan manusia karena pendidikan sudah merupakan bagian kebutuhan yang mendasar bagi setiap individu bahkan dari golongan manapun pendidikan sangatlah dibutuhkan. Di Indonesia kualitas pendidikan perlu ditingkatkan mengingat persaingan global sesuai dengan perkembangan zaman. Dalam hal meningkatkan kualitas pendidikan perlu adanya peran para pendidik atau guru dalam merancang pembelajaran di dalam kelas agar siswa mendapatkan pembelajaran yang bermakna dan dirancang melalui suatu kurikulum pendidikan.

Pembelajaran Tematik adalah pembelajaran tepadu yang menggunakan tema untuk mengaitkan beberapa mata pelajaran sehingga dapat memberikan pengalaman kepada siswa Nurdin, dkk, (2010:303). Sedangkan menurut Rusman (2012:254) Model pembelajaran tematik adalah model pembelajaran terpadu yang menggunakan pendekatan tematik dengan melibatkan beberapa mata pelajaran untuk memberikan pengalaman bermakna kepada siswa. Jadi pembelajaran tematik merupakan pendekatan pembelajaran yang mengaitkan mata pelajaran menjadi satu tema yang berkaitan untuk memberikan pengalaman bermakna kepada siswa. Melalui pembelajaran tematik siswa mendapatkan pengalaman langsung dalam proses pembelajarannya, seharusnya diharapkan dapat menambah daya kemampuan berpikir kreatif siswa semakin kuat tentang hal-hal yang di pelajarinya. Dikenyataan yang ada dilapangan implementasi pembelajaran tematik di sekolah dasar (SD) belum sebagaimana yang diharapkan.

Masih banyak guru yang merasa belum siap dalam melaksanakan pembelajaran tematik, terutama dalam menyusun rencana pelaksanaan pembelajaran tematik tetapi hanya sebagai formalitas saja. Disamping itu, guru masih sulit untuk meninggalkan kebiasan kegiatan pembelajaran yang penyajiannya berdasarkan mata pelajaran/bidang studi. Hal ini terjadi karena guru belum mendapat pelatihan tentang pembelajaran tematik ini secara intensif.

Berdasarkan observasi yang dilakukan di SD Negeri Mangunsari 03 Salatiga kelas IV pada pembelajaran tematik. Dapat diketahui bahwa ketika proses pembelajaran berlangsung guru sering menggunakan metode ceramah, sehingga proses pembelajaran yang selama ini dilaksanakan kurang memberikan ruang kepada siswa untuk mengolah pemikirannya secara mandiri. Keterbatasan pengetahuan yang mereka dapat dalam pembelajaran dapat mengakibatkan kurangnya kemampuan berpikir kreatif yang dimiliki siswa dan hal ini juga akan berdampak pada hasil belajar yang belummencapai Kriteria Ketuntasan Maksimum (KKM).

Melihat hasil observasi yang sudah dilakukan, maka dalam meningkatkan kemampuan berpikir kreatif dan hasil belajar dilakukan dengan cara merancang pembelajaran yang menarik. Pramudita \& Anugraheni (2017:72) berpendapat bahwa pembelajaran adalah suatu aktivitas guru dalam merancang pembelajaran yang mampu mengaktifkan siswa selama proses pembelajaran. Penelitian ini dilakukan dengan menerapkan model pembelajaran Problem Based Learning (PBL) dimana model pembelajaran ini akan membantu siswa untuk memecahkan suatu permasalahan atau mecari solusi dari permasalahan dari dunia nyata. Seperti yang dikemukakan oleh (Abidin, 2014:159) model pembelajaran berbasis masalah dilakukan dengan adanya pemberian rangsangan berupa masalah-masalah yang kemudian dilakukan pemecahan masalah oleh peserta didik yang diharapkan dapat menambah keterampilan peserta didik dalam pencapaian materi pembelajaran.

Langkah-langkah pembelajaran dalam model pembelajaran Problem Based Learning (PBL) menurut Menurut Ibrahim dan Nur (dalam Rusman, 2010:243) 1) Orientasi siswa pada masalah guru menjelaskan tujuan pembelajaran, menjelaskan logistik yang diperlukan, dan memotivasi siswa terlibat pada aktivitas pemecahan masalah. 2) Mengorganisasi siswa untuk belajar guru membantu siswa mendefinisikan dan mengorganisasikan tugas belajar
yang
berhubungan
dengan
masalah
tersebut.
3) Membimbing
pengalaman 
individual/kelompok guru mendorong siswa untuk mengumpulkan informasi yang sesuai, melaksanakan eksperimen untuk mendapatkan penjelasan dan pemecahan masalah. 4) Mengembangkan dan menyajikan hasil karya guru membantu siswa dalam merencanakan dan menyiapkan karya yang sesuai seperti laporan, dan membantu mereka untuk berbagi tugas dengan temannya. 5) Menganalisis dan mengevaluasi proses pemecahan masalah guru membantu siswa untuk melakukan refleksi atau evaluasi terhadap penyelidikan mereka dan proses yang mereka lakukan.

Model pembelajaran Problem Based Learning (PBL) ini membantu siswa untuk memecahkan atau mencari solusi secara mandiri atau berkemlompok dari pemasalahan dunia nyata. Sehingga dalam pelaksanaan pembelajaran siswa akan memperlihatkan kemampuan berpikir kreatifnya dan hasil pemahaman siswa akan materi yang disampaikan dapat diterima oleh siswa akan menghasilkan hasil belajar yang maksimal karena proses pembelajaran yang tidak membosankan. Johnson (2002:100) menyebutkan bahwa berpikir kreatif -yang mensyaratkan ketekunan, disiplin pribadi dan perhatian- melibatkan aktifitasaktifitas mental seperti mengajukan pertanyaan, mempertimbangkan informasi-informasi baru dan ide-ide yang tidak biasanya dengan suatu pikiran terbuka, membuat hubunganhubungan, khususnya antara sesuatu yang tidak serupa, mengkaitkan satu dengan lainnya dengan bebas, menerapkan imaginasi pada setiap situasi yang membangkitkan ide baru dan berbeda, dan memperhatikan intuisi. Sedangkan menurut Bono, (2007:35) berpikir kreatif suatu keterampilan untuk mendayagunakan kecerdasan berdasarkan pengalaman, bukanlah bakat tetapi kemampuan yang dapat di pelajari dan dilatih. Berdasarkan pendapat dari beberapa ahli diatas dapat disimpulkan bahwa berpikir kreatif adalah kemampuan yang dimiliki seseorang untuk memechakan masalah atau solusi berdasarkan hasil pemikirannya sendiri. Pengukuran berpikir kreatif dalam penelitian ini mengacu pada indikator berpikir kreatif yang dikembangkan oleh Liliawati dan Puspita (2010:265) yaitu Kelancaran (fluency), Keluwesan (flexibility), Keaslian (originality), dan Penguraian (elaboration).

Kegiatan belajar mengajar di sekolah memiliki tujuan yaitu hasil belajar yang baik. Dimyati dan Mudjiono (2013: 3) berpendalat hasil belajar merupakan hasil dari suatu interaksi tindak belajar dan tindak mengajar. Dari sisi guru, tindak mengajar diakhiri dengan proses evaluasi hasil belajar. Dari sisi siswa, hasil belajar merupakan berakhirnya penggal dan puncak proses belajar. Nawawi (dalam Susanto, 2013: 5) yang menyatakan bahwa hasil belajar dapat diartikan sebagai tingkat keberhasilan siswa dalam mempelajari materi pelajaran di sekolah yang dinyatakan dalam skor yang diperoleh dari hasil tes mengenal sejumlah materi pelajaran tertentu. Hal ini sesuai dengan pendapat dari Anugraheni (2017:249) hasil belajar siswa dapat diukur dengan menggunakan tes hasil belajar atau prestasi belajar ataupun achievement test. Berdasarkan pendapat dari beberapa para ahli diatas maka dapat disimpulkan bahwa hasil belajar adalah kemampuan yang dimiliki seseorang berdasarkan pengalaman belajarnya baik dari segi psikomotorik, kognitif, dan afektif yang dapat diukur menggunakan serangkaian tes.

\section{Metode}

Jenis penelitian ini adalah penelitian tindakan kelas (PTK). Penelitian tindakan kelas menurut Sanjaya (2013:149) merupakan proses pengkajian masalah pembelajaran didalam kelas melalui refleksi diri dan upaya untuk memecahkannya dengan cara melakukan berbagai tindakan yang terencana dalam situasi nyata serta menganalisis setiap pengaruh dari tindakan tersebut. Penelitian tindakan kelas ini dirancang untuk dilaksanakan dalam dua siklus. Setiap siklus dilakukan dalam empat tahapan sesuai dengan prosedur Arikunto (2007:16) yang terdiri dari perencanaan (Planning), pelaksanaan (Acting), pengamatan (Observing), dan refleksi (Reflecting). Penelitian ini menggunakan model pembelajaran Problem Based Learning (PBL) dilakukan di SD Negeri Mangunsari 03 Salatiga semester 2 tahun pelajaran 2017/2018 mulai bulan april sampai dengan mei 2018. Subjek penelitian ini adalah siswa kelas IV SD Negeri Mangunsari 03 Salatiga semester 2 tahun pelajaran 2017/2018 yang berjumlah 38 siswa, terdiri dari 15 siswa perempuan dan 23 siswa laki-laki. Teknik pengumpulan data pada hasil belajar siswa menggunakan soal evaluasi sejumlah 30 
soal pilihan ganda. Hasil belajar siswa dinyatakan berhasil apabila hasil belajar siswa mencapai KKM yaitu 70 pada setiap siklusnya. Sedangkan pada kemampuan berpikir kreatif siswa diperoleh hasil dengan cara observasi melalui lembar observasi yang di isi pada saat kegiatan pembelajaran pra siklus, siklus I, dan siklus II. Pada kemampuan berpikir kreatif siswa dikatakan berhasil apabila mencapai kriteria keberhasilan yang ditetapkan yaitu $80 \%$.

\section{Hasil dan Pembahasan}

Berdasarkan hasil penelitian yang telah dilakukan, menunjukkan bahwa pembelajaran dengan menerapkan model Problem Based Learning (PBL) mengalami peningkatan. Hal ini ditunjukkan dengan perubahan baik pada hasil belajar dan kemampuan berpikir kreatif siswa yang terjadi pada siklus I, siklus II apabila dibandingkan pada pra siklus. Agar dapat mengetahui tingkat keberhasilan dari penerapan model pembelajaran Problem Based Learning (PBL) pada Tema 7 Subtema 2 dan Subtema 3 siswa dan juga kemampuan berpikir kreatif siswa yang diperoleh pada siklus dan setelah penerapan model PBL pada siklus I dan siklus II. Hasil perbandingan tersebut disajikan pada tabel berikut ini.

Tabel 1 Perbandingan Kemampuan Berpikir Kreatif Siswa Kelas IV SD Negeri Mangunsari 03 Salatiga Pada Pra Siklus, Siklus I, dan Siklus II

\begin{tabular}{llllllll}
\hline No. & Kategori & $\begin{array}{l}\text { Prasiklus } \\
\text { Jumlah } \\
\text { Siswa }\end{array}$ & $\%$ & $\begin{array}{l}\text { Siklus I } \\
\text { Jumlah } \\
\text { Siswa }\end{array}$ & $\%$ & \multicolumn{3}{c}{$\begin{array}{l}\text { Siklus II } \\
\text { Jumlah } \\
\text { Siswa }\end{array}$} & $\%$ \\
\hline 1 & Sangat Tinggi & 9 & $23,68 \%$ & 13 & $32,21 \%$ & 15 & $39,44 \%$ \\
2 & Tinggi & 10 & $26,36 \%$ & 11 & $28,95 \%$ & 12 & $31,56 \%$ \\
3 & Cukup & 8 & $21,08 \%$ & 9 & $23,68 \%$ & 7 & $18,42 \%$ \\
4 & Rendah & 6 & $15,78 \%$ & 3 & $7,89 \%$ & 4 & $10,58 \%$ \\
5 & Sangat Rendah & 5 & $13,15 \%$ & 2 & $5,28 \%$ & 0 & $0 \%$ \\
Kategori Tinggi & 27 & $71,06 \%$ & 33 & $86,84 \%$ & 34 & $89,47 \%$ \\
Kategori Rendah & 11 & $28,94 \%$ & 5 & $13,16 \%$ & 4 & $10,53 \%$ \\
\hline
\end{tabular}

Perbandingan tabel perbandingan kemampuan berpikir kreatif siswa kelas IV SD Negeri Mangunsari 03 Salatiga dapat dilihat bahwa kemampuan berpikir kreatif siswa setiap siklusnya mengalami peningkatan. Dari hasil rekapitulasi pada tabel 1 dapat dilihat bahwa kemampuan berpikir kraetif siswa kelas IV SD Negeri Mangunsari 03 Salatiga sangat meningkat. Berdasarkan kategori sangat tinggi pada pra siklus kemampuan berpikir kreatif siswa sebanyak 9 siswa (23,68\%), pada siklus I meningkat menjadi 13 siswa $(32,21 \%)$, kemudian pada siklus II meningkat menjadi 15 siswa $(39,44 \%)$. Kategori tinggi pada pra siklus sebanyak 10 siswa (26,36\%), kemudian pada siklus I meningkat menjadi 11 siswa (28,95\%), dan pada siklus II meningkat menjadi 12 siswa $(31,56 \%)$. Kategori cukup pada pra siklus sebanyak 8 siswa $(21,08 \%)$, kemudian pada siklus I meningkat menjadi 9 siswa $(23,68 \%)$, dan pada siklus II menurun menjadi 7 siswa $(18,42 \%)$. Kategori rendah pada pra siklus sebanyak 6 siswa (15,78\%), kemudian pada siklus I mengalami penurunan menjadi 3 siswa $(7,89 \%)$, dan pada siklus II menurun meningkat menjadi 4 siswa (10,58\%). Kategori sangat rendah pada pra siklus sebanyak 5 siswa (13,15\%), kemudian pada siklus I menurun sebanyak 2 siswa (5,28\%), dan pada siklus II mengalami penurunan sebanyak 0 siswa (0\%). 
Tabel 2 Perbandingan Hasil Belajar Siswa Kelas IV SD Negeri Mangunsari O3 Salatiga pada Pra Siklus, Siklus I, dan Siklus II

\begin{tabular}{|c|c|c|c|c|c|c|c|c|}
\hline \multirow[t]{2}{*}{ No. } & \multirow{2}{*}{$\begin{array}{l}\text { Ketuntasan } \\
\text { Belajar }\end{array}$} & \multirow[b]{2}{*}{ Nilai KKM } & \multicolumn{2}{|c|}{ Prasiklus } & \multicolumn{2}{|l|}{ Siklus I } & \multicolumn{2}{|l|}{ Siklus II } \\
\hline & & & $\begin{array}{l}\text { Banyak } \\
\text { Siswa }\end{array}$ & $\%$ & $\begin{array}{l}\text { Banyak } \\
\text { Siswa }\end{array}$ & $\%$ & $\begin{array}{l}\text { Banyak } \\
\text { Siswa }\end{array}$ & $\%$ \\
\hline 1 & Tuntas & $\geq 70$ & 21 & $55,26 \%$ & 30 & $78,94^{\circ} \%$ & 33 & $86,84 \%$ \\
\hline 2 & Tidak Tuntas & $<70$ & 17 & $44,74 \%$ & 8 & $21,06 \%$ & 5 & $13,16 \%$ \\
\hline Jumlah & & & 38 & $100 \%$ & 38 & $100 \%$ & 38 & $100 \%$ \\
\hline Nilai Ra & rata & & 72,46 & & 76,26 & & 84,36 & \\
\hline
\end{tabular}

Berdasarkan tabel diatas, maka dapat dilihat perbandingan ketuntasan hasil belajar siswa dari kegiatan pembelajaran pra siklus, siklus I, dan siklus II dengan penerapan model Problem Based Learning (PBL) pada Tema 7 Subtema 2 dan Subtema 3 dapat diuraikan bahwa sebelumnya adanya tindakan terdapat 17 siswa dengan presentase $(44,74 \%)$ yang hasil belajarnya belum mencapai KKM (70) dan sisanya mendapat nilai memenuhi KKM. Setelah diberikan tindakan berupa model pembelajaran Problem Based Learning (PBL) terjadi peningkatan pada siswa yang mendapat nilai memenuhi KKM yakni sebanyak 30 siswa dengan presentase $(78,94 \%)$ dan tersisa 8 anak yang mendapat nilai belum memenuhi KKM. Sedangkan pada pemberian tindakan lanjutan yaitu pada siklus II jumlah siswa yang mendapat nilai memenuhi KKM sebanyak 33 siswa dengan presentase $(86,84 \%)$ dan hanya menyisakan 5 siswa yang masih belum memenuhi KKM. Berikut disajikan dalam bentuk diagram perbandingan ketuntasan hasil belajar siswa dari pra siklus, siklus I, dan siklus II.

Berdasarkan hasil penelitian yang sudaha dilaksanakan pada siswa kelas IV SD Negeri Mangunsari 03 Salatiga semester II tahun ajaran 2017/2018 dengan menggunakan model pembelajaran Problem Based Learning ( $\mathrm{PBL}$ ) menunjukkan adanta peningkatan kemampuan berpikir kreatif dan hasil belajar pada tiap siklus kemampuan berpikir kreatif dan hasil belajar pada tiap siklusnya dari pra siklus, siklus I hingga siklus II.

Peningkatan kemampuan berpikir kreatif pada pembelajaran tematik dapat dilihat pada pra siklus yang menujukkan kategori sangat tinggi terdapat 9 siswa siswa $(23,68 \%)$, meningkat pada siklus I menjadi 13 siswa $(32,21 \%)$ dan pada siklus II kembali meningkat menjadi 15 siswa $(39,44 \%)$. Pada kategori tinggi terdapat 10 siswa $(26,36 \%)$, meningkat pada siklus I menjadi 11 siswa (28,95\%) dan pada siklus II kembali meningkat menjadi 12 siswa (31,56\%). Pada kategori cukup terdapat 8 siswa $(21,08 \%)$, meningkat pada siklus I menjadi 9 siswa $(23,68 \%)$ dan terjadi penurunan pada siklus II menjadi 7 siswa $(18,42 \%)$. Pada kategori rendah terdapat 6 siswa $(15,78 \%)$, mengalami penurunan pada siklus I terdapat 3 siswa $(7,89 \%)$ kemudian pada siklus II mengalami sedikit peningkatan terdapat 4 siswa (10,58\%). Pada kategori sangat rendah terdapat 5 siswa $(13,15 \%)$, mengalami penurunan pada siklus I terdapat 2 siswa $(5,28 \%)$ dan pada siklus II terjadi penurunan yang terdapat 0 siswa (0\%). Berdasarkan data diatas, diperoleh presentase kemampuan berpikir kreatif yang menunjukkan peningkatan pada pra siklus sebanyak $71,06 \%$, kemudian meningkat pada siklus I menjadi $86,84 \%$ dan kembali meningkat pada siklus II menjadi $89,47 \%$. Hasil penelitian ini sesuai dengan penelitian yang sudah dilakukan sebelumnya oleh Rizal Abdurrozak, Asep Kurnia Jayadinata, dan Isrok'atun Isrok'atun (2016) dengan menggunakan model pembelajaran Problem Based Learning (PBL) pada pembelajaran untuk mengetahui hasil belajar siswa dapat meningkatkan kemampuan berpikir kreatif.

Selanjutnya, peningkatan pada hasil belajar siswa dapat dilihat dari pra siklus terdapat 21 siswa yang sudah tuntas (55,26\%) dan 17 siswa yang tidak tuntas (44,74\%). Kemudian pada siklus I terjadi peningkatan, hal ini ditunjukkan dengan adanya 30 siswa yang sudah tuntas $(78,94 \%)$ dan 8 siswa yang tidak tuntas $(21,06 \%)$. Pada siklus II kembali meningkat, hal ini ditunjukkan dengan adanya 33 siswa yang sudah tuntas (86.84\%) dan 5 siswa yang tidak tuntas (13,16\%). Hasil penelitian ini sesuai dengan penelitian yang sudah dilakukan 
sebelumnya oleh oleh Eni Karlina (2016) dimana tes hasil belajar Subtema Kebersamaan Dalam Keberagaman sudah dilakukan dengan menerapkan model pembelajaran Problem Based Learning (PBL) dapat meningkatkan hasil belajar siswa. Penelitian ini juga sesuai dengan penelitian Yulfika Yasmin (2010) bahwa pada siklus I presentase ketuntasan hasil belajar dapat meningkat menggunakan model pembelajaran Problem Based Learning (PBL). Peningkatan hasil belajar dalam penelitian yang dikemukakan oleh Sudjana (2010:22) hasil belajar adalah kemampuan yang dimiliki siswa setelah menerima pengalaman belajar. Dapat disimpulkan bahwa penerapan model pembelajaran Problem Based Learning (PBL) dapat meningkatkan kemampuan berpikir kreatif siswa dan hasil belajar pada pembelajaran tematik kelas IV SD Negeri Mangunsari 03 Salatiga dalam penelitian ini. Keunggulan dari penelitian ini dibanding dengan penelitian lain yaitu dalam penelitian ini mengukur kemampuan berpikir kreatif dan hasil belajar siswa. Pengukuran kemampuan berpikir kreatif menggunakan rubrik penilaian dimana siswa dapat melakukan tindakan sesuai yang sudah diberikan oleh guru. Rubrik penilaian terdiri dari sangat tinggi, tinggi, cukup, rendah dan sangat rendah. Selain itu siswa melakukan tugas sesuai dengan materi yang diajarkan, dimana siswa dapat mempresentasikannya di depan kelas. Sedangkan hasil belajar siswa dapat diukur dengan mengerjakan soal evaluasi yang sudah diberikan oleh guru.

\section{Simpulan dan Saran}

Berdasarkan hasil penelitian dan pembahasan, maka dapat disimpulkan bahwa penggunaan model pembelajaran Problem Based Learning (PBL) dapat meningkatkan kemampuan berpikir kreatif dan hasil belajar siswa kelas IV SD Negeri Mangunsari 03 Salatiga, Semester II Tahun Pelajaran 2017/2018. Hal ini terlihat pada pra siklus, siklus I, dan siklus II peningkatan kemampuan berpikir kreatif siswa mengalami peningkatan dari pra siklus dengan presentase $71,06 \%$, kemudian pada siklus I meningkat menjadi $86,84 \%$, dan pada siklus II meningkat menjadi $89,47 \%$. Sedangkan hasil belajar siswa pada pra siklus, siklus I, dan siklus II mengalami peningkatan dari pra siklus dengan presentase $72,46 \%$, kemudian pada siklus I meningkat menjadi $76,26 \%$, dan pada siklus II mengalami peningkatan menjadi 84,36\%. Maka dapat disimpulkan bahwa penerapan model pembelajaran Problem Based Learning (PBL) dapat meningkatkan kemampuan berpikir kreatif dan hasil belajar siswa pada pembelajaran tematik kelas IV SD Negeri Mangsunsari 03.Berdasarkan kesimpulan yang telah dipaparkan peneliti menyarankan beberapa hal yang perlu diperhatikan: 1) Bagi siswa dituntut tidak pasif dalam proses pembelajaran yang sedang dilaksanakan sehingga siswa diharapkan akan memiliki kreativitas dan hasil belajar yang meningkat pada setiap pembelajaranya. 2) Bagi guru dapat menjadikan referensi model pembelajaran Problem Based Learning (PBL) untuk menjadi solusi agar tujuan pembelajaran dapat tercapai dalam merancang pembelajaran yang akan dilaksanakan. 3) Bagi peneliti diharapkan dapat menerapkan ilmu yang telah didapatnya pada saat penelitian ke dalam dunia Pendidikan. Peneliti juga harus terus menambahkan referensi teori tentang model pembelajaran Problem Based Learning (PBL) sehingga dapat lebih mendalami model pembelajaran sehingga lebih kreatif dalam menggunakan alat peraga dan media belajar yang akan digunakan dalam pembelajaran.

\section{Daftar Pustaka}

Abdullah, A. G., \& Ridwan, T. (2008). Implementasi Problem Based Learning (PBL) pada Proses Pembelajaran di BPTP Bandung. Prosiding UPI, 1-10.

Abdulrozzak, R. (2016). Pengaruh Model Problem Based Learning Terhadap Kemampuan Berpikir Kreatif Siswa (Doctoral Dissertation, Universitas Pendidikan Indonesia).

Ahmad, Susanto. (2013). Teori Belajar dan Pembelajaran di Sekolah Dasar. Jakarta: Kencana Prenada Media Group 
Arikunto, Suharsimi. 2007. Dasar-Dasar Evaluasi Pendidikan. Jakarta: Bumi Aksara.

Anwar, M. S. (2015). Efektifitas Pembelajaran PBL (Problem Based Learning) Terhadap Kemampuan Berpikir Kritis Dan Kreatif Siswa Materi Tiga Dimensi (Doctoral dissertation, Universitas Terbuka).

Derin, N., Ani, N. A., \& Asep, K. J. (2016). PENGARUH MODEL PROBLEM BASED LEARNING TERHADAP KEMAMPUAN BERPIKIK KREATIF SISWA PADA MATERI PESAWAT SEDERHANA. Jurnal Pena IImiah, 1-10.

Gunantara, G., Suarjana, I. M., \& Riastini, P. N. (2014). Penerapan model pembelajaran problem based learning untuk meningkatkan kemampuan pemecahan masalah matematika siswa kelas V. MIMBAR PGSD Undiksha, 2(1).

Karlina, E. (2016). PENERAPAN MODEL PROBLEM BASED LEARNING UNTUK MENINGKATKAN KERJA SAMA DAN HASIL BELAJAR SISWA KELAS IV SDN BHAKTI WINAYA BANDUNG PADA SUBTEMA KEBERSAMAAN DALAM KEBERAGAMAN (Doctoral dissertation, FKIP UNPAS).

Khoiri, W., Rochmad, R., \& Cahyono, A. N. (2013). Problem based learning berbantuan multimedia dalam pembelajaran matematika untuk meningkatkan kemampuan berpikir kreatif. Unnes Journal of Mathematics Education, 2(1).

Khotimah, K., Suhartono, S., \& Salimi, M. (2017). Penerapan Model Problem Based Learning Untuk Meningkatkan Hasil Belajar Matematika Tentang Perkalian Dan Pembagian Pecahan Pada Siswa Kelas V SDN 1 Tamanwinangun Tahun Ajaran 2016/2017. Kalam Cendekia PGSD Kebumen, 5(2.1).

Kurniasih, S. (2014). Strategi-Strategi Pembelajaran. Bandug: Alfabeta.

Kristin, F. (2016). Efektivitas Model Pembelajaran Kooperatif Tipe Stad Ditinjau Dari Hasil Belajar IPS Siswa Kelas 4SD. Scholaria: Jurnal Pendidikan dan Kebudayaan, 6(2), 74-79.

Moma, L. (2016). Pengembangan Instrumen Kemampuan Berpikir Kreatif Matematis Untuk Siswa SMP. Delta-Pi: Jurnal Matematika dan Pendidikan Matematika, 4(1).

Nurdin, Diding, dkk. 2010. Problematika Pendidikan Dasar Kebijakan, Strategi dan Metode Pembelajaran. Bandung: IImu Cahaya Hati.

Nurhidayat, F. (2015). PENERAPAN MODEL PEMBELAJARAN TEMATIK (WEBBED) DENGAN MEDIA VISUAL DALAM PENINGKATAN PEMBELAJARAN TEMA PENDIDIKAN DI KELAS III SDN 1 PURWOGONDO TAHUN AJARAN 2014/2015. KALAM CENDEKIA PGSD KEBUMEN, 3(5.1).

Noer, S. H. (2011). Kemampuan berpikir kreatif matematis dan pembelajaran matematika berbasis masalah Open-Ended. Jurnal Pendidikan Matematika, 5(1).

Risnawati, R., \& Saadi, P. (2017). Meningkatkan Kemampuan Berpikir Kreatif Dan Hasil Belajar Melalui Model Pembelajaran Creative Problem Solving (CPS) Pada Materi Larutan Penyangga. Quantum: Jurnal Inovasi Pendidikan Sains, 7(2), 127-134.

Sanjaya, Wina. 2012. Penelitian Tindakan Kelas Cetakan II. Jakarta : Kencana Prenada Media Group.

Saefudin, A. A. (2012). Pengembangan kemampuan berpikir kreatif siswa dalam pembelajaran matematika dengan pendekatan pendidikan matematika realistik indonesia (PMRI). Jurnal AlBidāyah, 4(1).

Sudjana, Nana. 2010. Cara Belajar Siswa Aktif dalam Proses Belajar Mengajar. Bandung: Sinar Baru Algensindo. 
Sudrajat, A. (2013, Januari 20). Pendekatan Dan Metode Pembelajaran Dalam Kurikulum 2013. hal. 1

Sudrajat, Akhmad . (2008). Pengertian pemahaman dalam pembelajaran. http://akhmadsudrajat.wordpress.com/2008/07/13/pembelajaran-tematik-di-kelas-awalsekolah-dasar/ Diakses dalam laman web tanggal 31 maret 2014 pukul 17:05

Sugiyono. 2011. Metodologi Penelitian Kuantitatif, Kualitatif dan R\&D. Bandung: Alfabeta Bandung.

Triwiyanto, Teguh. 2014. Pengantar Pendidikan, Jakarta: PT Bumi Aksara

Utomo, T., Wahyuni, D., \& Hariyadi, S. (2014). Pengaruh Model Pembelajaran Berbasis Masalah (Problem Based Learning) Terhadap Pemahaman Konsep dan Kemampuan Berpikir Kreatif Siswa (Siswa Kelas VIII Semester Gasal SMPN 1 Sumbermalang Kabupaten Situbondo Tahun Ajaran 2012/2013). Jurnal Edukasi, 1(1), 5-9.

Yasmin, Y. (2010). Penerapan problem based learning untuk meningkatkan motivasi dan hasil belajar dalam pembelajaran bahasa Indonesia siswa kelas V SDN Tegalweru Kecamatan Dau Kabupaten Malang. Penerapan problem based learning untuk meningkatkan motivasi dan hasil belajar dalam pembelajaran bahasa Indonesia siswa kelas V SDN Tegalweru Kecamatan Dau Kabupaten Malang/Yulfika Yasmin.

Pramudita, W., \& Anugraheni, I. (2017). Studi Penguasaan Matematika dan Bahasa Inggris Mahasiswa Program Studi Pendidikan Guru Sekolah Dasar (PGSD). Scholaria\&58; Jurnal Pendidikan dan Kebudayaan, 7(1), 70-82.

Vitasari, R. (2013). Peningkatan Keaktifan dan Hasil Belajar Matematika Melalui Model Problem Based Learning Siswa Kelas V SD Negeri 5 Kutosari. Kalam Cendekia PGSD Kebumen, 4(3).

Wijaya, L., Rochmad, R., \& Agoestanto, A. (2016). Analisis Kemampuan Berpikir Kreatif Matematis Siswa Smp Kelas Vii Ditinjau Dari Tipe Kepribadian. Unnes Journal of Mathematics Education, 5(2). 